Original article

Section: Nutritional Research

\title{
Nutritional Properties, Antioxidant and Antihaemolytic Activities of the Dry Fruiting Bodies of Wild Edible Mushrooms Consumed by Ethnic Communities of Northeast India
}

\author{
Merilin Kakoti ${ }^{1,2} \oplus^{\oplus}$, Dibya Jyoti Hazarika $^{1,3}{ }^{\oplus}$, Assma Parveen $^{1}{ }^{\oplus}$, Samim Dullah $^{1}{ }^{\oplus}$,

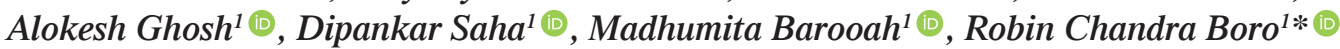 \\ ${ }^{1}$ Department of Agricultural Biotechnology, Assam Agricultural University, Jorhat - 785013, Assam, India \\ ${ }^{2}$ Department of Bioengineering and Technology, Gauhati University Institute of Science and Technology, \\ Gauhati University, Guwahati - 781014, Assam, India \\ ${ }^{3}$ DBT-North East Centre for Agricultural Biotechnology, Assam Agricultural University, Jorhat - 785013, Assam, India
}

Key words: antihaemolytic activity, basidiomycota, radical scavenging activity, nutrients, organic acids, phenolic acids

A variety of cultivated mushrooms in Northeast India are well known for their taste, nutritional and medicinal benefits. Many wild-growing mushrooms are also consumed due to their exotic flavours and tastes; however, the scientific exploration of their nutritional and bioactive properties is still negligible. In the present study, the 32 wild edible mushroom samples of 11 species collected from different parts of Northeast India were evaluated for their proximate composition, mineral and vitamin (ascorbic acid and riboflavin) contents, antioxidant and antihaemolytic activity, and profiles of organic and phenolic acids. Lentinus sajor-caju and Lentinus squarrosulus had the highest carbohydrate content (49.80 g/100 g dry weight (d.w.) and $46.36 \mathrm{~g} / 100 \mathrm{~g} \mathrm{~d}$.w., respectively), crude protein content $(20.72 \mathrm{~g} / 100 \mathrm{~g} \mathrm{~d} . \mathrm{w}$. and $20.54 \mathrm{~g} / 100 \mathrm{~g}$ d.w., respectively) and a considerable content of minerals. The highest fat content was determined in Lentinus velutinus (7.17 g/100 g d.w.). Among the minerals, potassium was found as the most abundant in all the samples. The extracts of L. sajor-caju, L. squarrosulus, and Pleurotus pulmonarius were characterized by the highest antioxidant activity, while these of L. sajor-caju, Pleurotus ostreatus, P. pulmonarius and Agaricus bisporus showed the highest antihaemolytic potential. The HPLC analysis allowed determining the high contents of ascorbic acid and a few organic and phenolic acids such as lactic acid, gallic acid, 3,4-dihydroxybenzoic acid and trans-cinnamic acid in the tested mushrooms. Other compounds viz. citric acid, caffeic acid, riboflavin, vanillic acid, pyruvic acid, and $p$-coumaric acid were detected with variations. This study established the nutritional and health benefits of wild edible mushrooms of Northeast India region for consumption as functional foods in the human diet.

\section{INTRODUCTION}

Mushrooms (including the members of Basidiomycota and the fruiting body forming Ascomycota) are considered to be one of the important components of the forest ecosystem. They have been gaining in importance since ancient times due to their edibility, psychotropic properties, poisonous nature, and mycorrhizal or parasitic associations with the forest trees. With an estimation of around 1.5 million fungal species on earth [Hawksworth, 2001], more than 31,000 species of Basidiomycota (which form the fruiting bodies) and more than 66,000 species of Ascomycota (a small fraction of which forms the fruiting bodies) are well-characterized [Martins, 2017; Taylor et al., 2015]. Among the discovered mushroom species, there are abundant numbers of wild edible mushrooms which are consumed world-wide. These mushrooms need to be evaluated for their nutritional composition and bioactive metabolites.
Many mushrooms are rich in nutrients, medicinal, and plant growth-promoting compounds [Ghate \& Sridhar, 2016], whereas, many others contain toxic metabolites. Edible mushrooms contain considerable amount of nutritional compounds including carbohydrates (especially non-reducing sugars), proteins, minerals and vitamins. Presence of phenolics, tocopherols, carotenoids and ascorbic acid in mushroom fruiting bodies make them a good source of natural antioxidants [Sánchez, 2017]. These antioxidant molecules provide biochemical support to the growth of fruiting bodies by neutralizing the oxidative stresses provided by reactive oxygen species and free radicals. Likewise, consumption of foods that are rich in natural antioxidants provide excellent health benefits and protects our body against oxidative stresses and aging signs [Chang, 1996; Lindequist et al., 2005]. Recent studies have demonstrated the antihaemolytic potential of a few mushroom species [Madhanraj et al., 2019; Sharif et al., 2017]. Antihaemolytic compounds are antioxidants that

\footnotetext{
* Corresponding Author:

E-mail: robin.boro@aau.ac.in (R.Ch. Boro)
} 
inhibit the lysis of red blood cells caused by oxidative agents [Shabbir et al., 2013].

The Northeast (NE) India possesses a richness in forests, with an abundance of many tree species and other woody plants. The biodiversity of woody plants can be correlated with an equally diverse mycoflora. Ethnic communities inhabiting different regions of Northeast India regularly consume edible mushrooms collecting from the wild based on their traditional knowledge on mushroom identities and their nutritional benefits. However, the diversity of wild mushrooms from this region is not well documented in terms of nutritional properties and bioactive properties. Earlier studies have identified some of the wild edible mushrooms from the states of NE India including Assam, Arunachal Pradesh, Meghalaya, and Nagaland [Khaund \& Joshi, 2013; Parveen et al., 2017; Sarma et al., 2010]. However, nutritional profiling of majority of these wild edible mushrooms are not well investigated. In our recent study, a molecular genetic analysis was conducted to identify 50 wild mushrooms collected from different regions of five Northeastern states of India, out of which 32 edible samples belonging to 11 different species were detected based on their morphological characters as well as genetic information of the internal transcribed spacer (ITS) region [Kakoti et al., 2021]. Most of these edible mushrooms are part of the regular diet of various tribal and non-tribal communities. Therefore, the present investigation was conducted to evaluate the species-wise nutritional profiling including proximate composition, mineral and vitamin (ascorbic acid and riboflavin) contents, bioactivity (antioxidant and antihaemolytic activities) and contents of organic and phenolic acids of those 32 wild edible mushrooms to establish their edibility as functional food.

\section{MATERIALS AND METHODS}

\section{Collection of the fruiting bodies of mushrooms}

The fruiting bodies of different mushrooms were collected from different locations of five North-Eastern states of India (Assam, Arunachal Pradesh, Manipur, Meghalaya, and Nagaland). The fruiting bodies were cleaned at the site of collection with distilled water and immediately taken to the laboratory by packing inside the collection bags. A total of 32 wild-edible mushroom samples were used in this study and their fundamental sampling information are described in Table 1. These information are also available online at Barcode of Life Data (BOLD) system (http://www.boldsystems.org/). Morphological description of molecular identities (ITS barcode details) of the samples was provided previously [Kakoti et al., 2021]. BOLD submission IDs and GenBank Accession numbers are provided in Table 1.

\section{Preparation of dry powder}

The mushroom fruiting bodies were initially shade-dried with dry air to remove the excessive moisture from the samples and placed in a hot air oven at $45^{\circ} \mathrm{C}$ until the residual moisture was removed. This process took 16-24 h depending on the sample characteristics. Dry mushrooms were then powdered using a grinder and sieved through $0.5 \mathrm{~mm}$ net.

\section{Determination of moisture content}

Moisture content of the fresh mushrooms was determined using the Association of Official Analytical Chemists (AOAC) standard protocol [AOAC, 1996]. Briefly, about $20 \mathrm{~g}$ of freshly collected samples were weighed, shade-dried at room temperature for $2 \mathrm{~h}$ inside a laminar air flow hood (to remove the excessive moisture), and placed in a hot-air oven at $105^{\circ} \mathrm{C}$ for $5 \mathrm{~h}$. The dishes were later cooled in a desiccator and weighed with the lid on. The moisture content of the mushrooms was estimated using the formula:

$$
\begin{aligned}
& \text { Moisture content of fresh sample }(\mathrm{g} / 100 \mathrm{~g}) \\
& =\left(\frac{\text { Fresh weight }(\mathrm{g})-\text { Dry weight }(\mathrm{g})}{\text { Fresh weight }(\mathrm{g})}\right) \times 100
\end{aligned}
$$

The residual moisture content in the dry fruiting powders was determined from $1 \mathrm{~g}$ dry powder by placing in a hot-air oven at $105^{\circ} \mathrm{C}$ for $5 \mathrm{~h}$.

Moisture content of dry powder (g/100 g)

$$
=\left(\frac{\text { Initial dry weight }(\mathrm{g})-\text { final dry weight }(\mathrm{g})}{\text { Initial dry weight }(\mathrm{g})}\right) \times 100
$$

Moisture content of the dry powder was used to calculate the actual dry weight of the samples.

\section{Determination of ash content}

The ash content of mushrooms was determined from the dried, fine powders of the mushroom fruiting bodies. One gram of powder was weighed into a crucible, which was placed in a muffle furnace initially at $130^{\circ} \mathrm{C}$ for $1 \mathrm{~h}$, and finally the temperature was increased to $600^{\circ} \mathrm{C}$ for about $6 \mathrm{~h}$. The powder was cooled in a desiccator and weighed. The ash content was calculated using the following equation:

$$
\begin{aligned}
& \text { Ash content }(\mathrm{g} / 100 \mathrm{~g}) \\
& \qquad=\left(\frac{\text { Weight of ash }(\mathrm{g})}{\text { Weight of dry mushroom }(\mathrm{g})}\right) \times 100
\end{aligned}
$$

Finally, ash content of dried mushrooms was expressed as g per $100 \mathrm{~g}$ of powder dry weight (d.w.).

\section{Determination of crude protein content}

The crude protein in the dried and powdered mushroom tissue was determined using the macro-Kjeldhal method [method 984.13; AOAC, 1990] with necessary modifications. Briefly, $100 \mathrm{mg}$ of the mushroom powder was subjected to acid digestion in a KelPlus digestion apparatus (Pelican equipment, Channai, Tamil Nadu, India). The digested sample was distilled following the alkali treatment and the released ammonia was extracted in $2.5 \%$ boric acid using the KelPlus automatic distiller (Pelican equipment). The resultant solution was then titrated manually against $0.02 \mathrm{~N}$ sulfuric acid to determine the nitrogen content. The crude protein content was calculated from the nitrogen content by multiplying with a factor of 4.38 [Reis et al., 2012]. The results were expressed as $\mathrm{g}$ per $100 \mathrm{~g}$ of d.w. of mushroom powders.

\section{Determination of total carbohydrate content}

Dried mushroom powder (100 mg) was mixed with $2.5 \mathrm{~N}$ $\mathrm{HCl}$ and boiled in a water bath for $3 \mathrm{~h}$. The hydrolysate was neutralized with sodium carbonate. The volume was made up 
to $100 \mathrm{~mL}$ and supernatant was collected by centrifugation. Carbohydrate content in the supernatant was determined using the anthrone method [Sadasivam \& Manickam, 1996]. Total carbohydrate content of mushroom powders was expressed as g per $100 \mathrm{~g}$ of d.w.

\section{Determination of fat content}

The total fat content of dried mushroom fruiting bodies was determined using the gravimetric method [AOAC, 2007]. Fat was extracted with ethanol : diethyl ether : petroleum ether $(5: 12: 12, v / v / v)$ after hydrolysis of the dry mushroom powder with concentrated $\mathrm{HCl}$. The petroleum ether layer was separated after proper mixing and dried to obtain the fat, which was further weighed. Total fat content in dried mushrooms was calculated as follows:

$$
\begin{aligned}
& \text { Fat content }(\mathrm{g} / 100 \mathrm{~g}) \\
& \qquad=\left(\frac{\text { Weight of the extracted fat }(\mathrm{g})}{\text { Sample weight }(\mathrm{g})}\right) \times 100
\end{aligned}
$$

The results were expressed as g per $100 \mathrm{~g}$ of d.w. of mushroom powders.

\section{Determination of mineral content}

The contents of minerals viz. calcium, magnesium, potassium, sodium, zinc, iron, copper and manganese, in the dried mushroom fruiting bodies were determined using an iCE3000 atomic absorption spectrometer (Thermo Scientific, Waltham, MA, USA). Extracts were prepared by digesting the powdered mushroom samples in nitric acid and hydrogen peroxide as described earlier [Soylak et al., 2005]. The phosphorus content was estimated using the molybdovanadate method [method 965.17; AOAC, 1990]. The content of each element was determined using a calibration curve plotted with known concentrations of the respective standards. Results were expressed based on d.w. of mushroom powders.

\section{Extract preparation from the fruiting bodies}

Dry powdered fruiting bodies ( $1 \mathrm{~g}$ ) were extracted overnight using $100 \mathrm{~mL}$ of methanol and the supernatant was carefully filtered through Whatman No. 42 filter paper (GE Healthcare, Chicago, IL, USA) taking the care that minimal residue was transferred to the filter paper. Supernatant was collected and the residue was extracted with another $100 \mathrm{~mL}$ of methanol as described above. For the determination of total phenolic content, the filtered supernatant was directly used in the assay. For antioxidant and antihaemolytic activities analysis, the extracts were evaporated to dryness using a rotary evaporator and re-dissolved in a required volume (to prepare the working solutions) of methanol or phosphate buffered saline (PBS; $10 \mathrm{mM} \mathrm{Na} \mathrm{HPO}_{4}, 1.8 \mathrm{mM} \mathrm{KH}_{2} \mathrm{PO}_{4}$, $137 \mathrm{mM} \mathrm{NaCl}$ and $2.7 \mathrm{mM} \mathrm{KCl}, \mathrm{pH}$ 7.4), respectively, as per the requirements for further experiments.

\section{Determination of total phenolic content}

Total phenolic content in the methanol extracts of mushroom samples was estimated spectrophotometrically, based on the procedure described by Singleton \& Rossi [1965] with some modifications. First, $1 \mathrm{~mL}$ of the extract was mixed with $1 \mathrm{~mL}$ of a Folin-Ciocalteu's phenol reagent. After 3 min,
$1 \mathrm{~mL}$ of a saturated sodium carbonate solution was added to the mixture and adjusted to the total volume to $10 \mathrm{~mL}$ with distilled water. The reaction mixture was kept in dark for $90 \mathrm{~min}$, after that the absorbance was recorded at $725 \mathrm{~nm}$. Known concentrations of gallic acid were used to prepare the standard curve. The total phenolic content of the samples was calculated based on the graph and expressed as mg gallic acid equivalents (GAE) per $100 \mathrm{~g}$ of d.w. of mushroom powders.

\section{DPPH radical scavenging activity}

The 2,2-diphenyl-1-picrylhydrazyl (DPPH, Sigma, Saint Louis, MO, USA) radical scavenging activity was determined by the Blois's method [Blois, 1958] with minor modifications. The extract and reference standard solutions in methanol $(1 \mathrm{~mL})$ were prepared in different concentrations and mixed individually with $0.5 \mathrm{~mL}$ of $0.15 \mathrm{mM} \mathrm{DPPH}{ }^{\bullet}$ solution. $\alpha$-Tocopherol was used as the reference standard [Boonsong et al., 2016]. The percentage of inhibition of DPPH` was obtained by measuring the absorbance at $517 \mathrm{~nm}$ using an Evolution 202 UV-Vis double beam spectrophotometer (Thermo Scientific) and calculation using the following formula:

$$
\begin{aligned}
& \% \text { Inhibition of DPPH radical } \\
& \qquad=\left(\frac{\text { Absorbance of control - Absorbance of sample }}{\text { Absorbance of control }}\right) \times 100
\end{aligned}
$$

The $\%$ inhibition data was used to calculate the $\mathrm{IC}_{50}$ value - concentration of extract that could scavenge $50 \%$ of DPPH radicals. Additionally, the results were expressed as the tocopherol equivalent antioxidant activity (TEAA) in mg tocopherol equivalent per $100 \mathrm{~g}$ of d.w. of mushroom powder.

\section{Determination of antihaemolytic activity}

The antihaemolytic activity of the dried mushrooms was evaluated using the spectrophotometric method described previously by Shabbir et al. [2013] with minor modifications. Briefly, the reaction mixture consisted $0.5 \mathrm{~mL}$ of mushroom extract with varying concentrations viz., 100, 250, 500, 750 and $1000 \mu \mathrm{g} / \mathrm{mL}$ in PBS and $0.5 \mathrm{~mL}$ of a red blood cell (RBC) suspension, and the mixture was incubated at room temperature for $20 \mathrm{~min}$. After incubation, $0.5 \mathrm{~mL}$ of hydrogen peroxide $\left(\mathrm{H}_{2} \mathrm{O}_{2}\right)$ was supplemented to the mixture for induction of the oxidative degradation of membrane lipids. A control was prepared with a similar volume of the reaction mixture without adding the extract. The reaction mixture was then centrifuged at $500 \times g, 4^{\circ} \mathrm{C}$ for $5 \mathrm{~min}$ and the antihaemolytic activity was assessed spectrophotometrically at $540 \mathrm{~nm}$. The percent of haemolysis was calculated using the following formula:

$\%$ Inhibition of haemolysis

$$
=\left(\frac{\text { Absorbance of control }- \text { Absorbance of sample }}{\text { Absorbance of control }}\right) \times 100
$$

The $\%$ inhibition data was used to calculate the $\mathrm{IC}_{50}$ value - concentration of extract that could inhibit the haemolysis of RBC by $50 \%$.

\section{Detection of major organic acids and antioxidant compounds}

The organic and phenolic acids and some other metabolites were initially extracted from powdered mushroom 


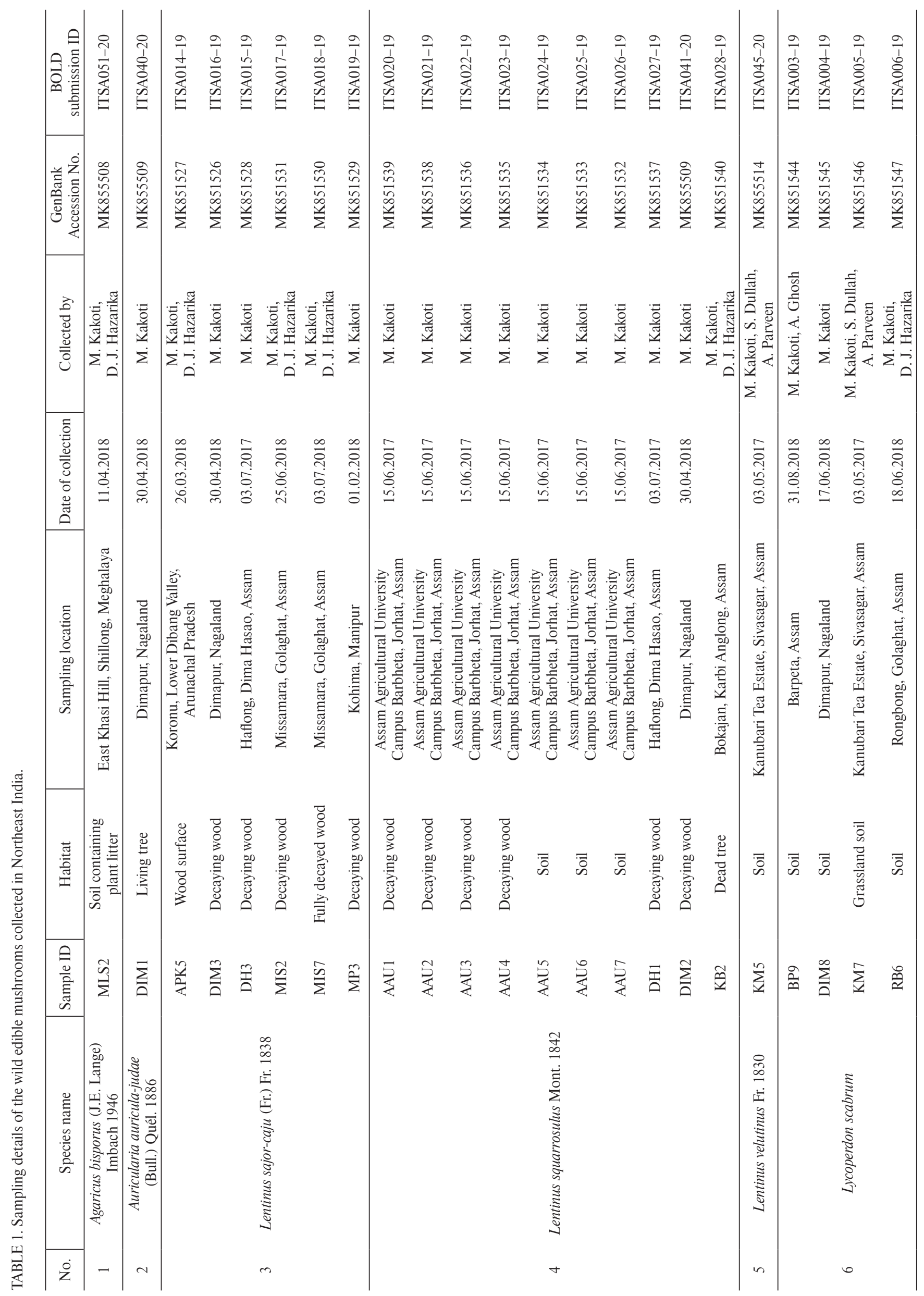




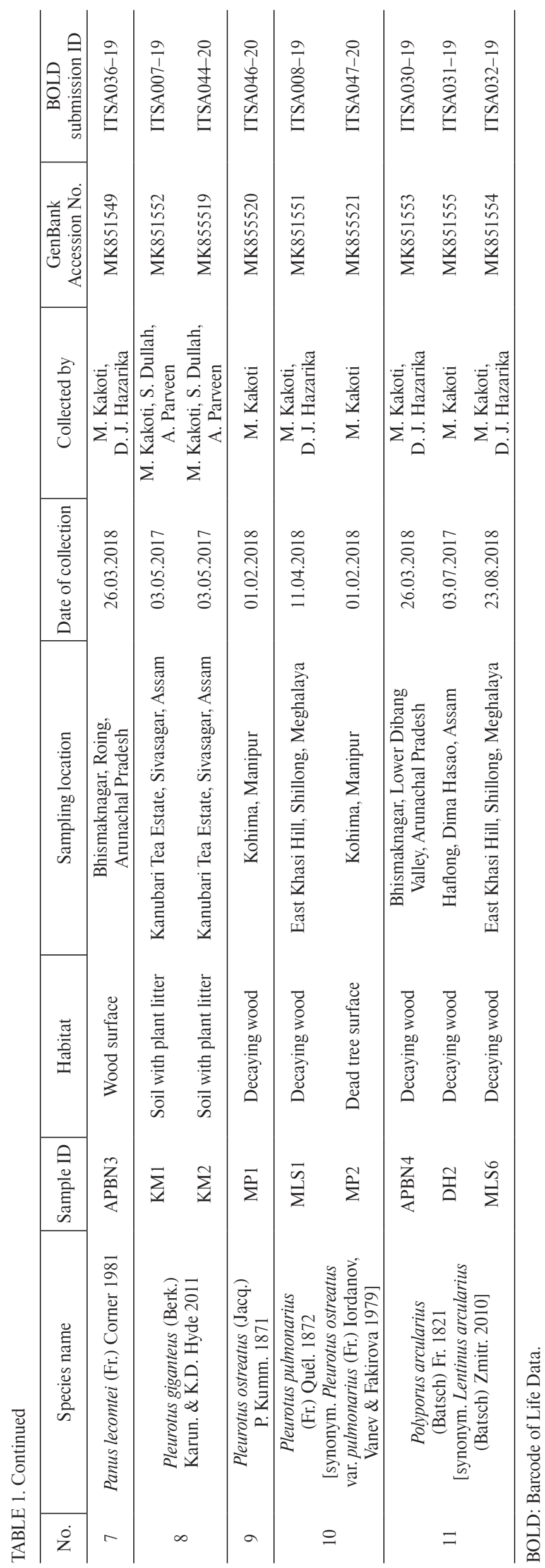

fruiting body $(1 \mathrm{~g})$ with $25 \mathrm{~mL}$ of $80 \%(\mathrm{v} / \mathrm{v})$ acetone in water [Barros et al., 2009] for $6 \mathrm{~h}$ and filtered through Whatman No. 42 filter paper (GE Healthcare) taking the care that minimal residue was transferred to the filter paper. The precipitate was re-extracted with another $25 \mathrm{~mL}$ of $80 \%(v / v)$ acetone as described above. The crude extracts were concentrated under vacuum and re-dissolved in $20 \mathrm{~mL}$ of $50 \%(\mathrm{v} / \mathrm{v})$ methanol. The extracts were then filtered using a membrane syringe filter and a $20 \mu \mathrm{L}$ of sample was separated through a Cosmosil C-18 column $(300 \times 4.6 \mathrm{~mm}$, pore size $5 \mu \mathrm{m}$; Nacalai Tesque Inc., Kyoto, Japan) installed in a Hitachi Chromaster 3000 series HPLC system with a diode array detector (Hitachi, Tokyo, Japan). The mobile phase used consisted of acetonitrile (A) and $0.1 \%(v / v)$ phosphoric acid $\left(\mathrm{H}_{3} \mathrm{PO}_{4}\right)$ in water in a gradient mode: $5 \%$ of $\mathrm{A}$ at $0-2 \mathrm{~min}, 15 \%$ of $\mathrm{A}$ at $2-5 \mathrm{~min}$, $40 \%$ of $A$ at $5-10 \mathrm{~min}, 60 \%$ of $A$ at $10-15 \mathrm{~min}, 90 \%$ of $\mathrm{A}$ at $15-$ $-18 \mathrm{~min}$, reverting to $5 \%$ of $\mathrm{A}$ at $20 \mathrm{~min}$ and equilibration with $5 \%$ of A till 25 min. Detection of compounds was performed in the range of 200-400 $\mathrm{nm}$. The peaks were compared with individual standards of 11 organic acids and antioxidants viz: ascorbic acid (Sigma-Aldrich, Saint Louis, MO, USA), caffeic acid (Sigma-Aldrich), citric acid (Himedia, Mumbai, Maharastra, India), 3,4-dihydroxybenzoic acid (Sigma-Aldrich), gallic acid (Sigma-Aldrich), lactic acid (Sigma-Aldrich), pyruvic acid (Himedia), $p$-coumaric acid (Sigma-Aldrich), riboflavin (Sigma-Aldrich), trans-cinnamic acid (Sigma-Aldrich) and vanillic acid (Sigma-Aldrich). The contents of compounds in mushrooms were calculated from the linear portion of the regression curve prepared from the peak areas of individual reference standards.

\section{Statistical analysis}

All the statistical analyses were performed using IBM SPSS software, version 25 (Armonk, NY, USA). To test the significant differences among the samples, one-way analysis of variance (ANOVA) with Duncan's multiple range test was used, while non-parametric Kruskal-Wallis test was used for species-wise comparison. Results were considered to be significant with $95 \%$ confidence level and $p<0.05$. Pearson's correlation analysis was performed to calculate the correlation coefficient among total phenolic content, antioxidant activity and antihaemolytic activity. All the experiments, including the preparation of extracts, determination of proximate compositions and bioactivities were performed with three independent replicates for each sample. Three data points were generated from three independent replications for statistical analysis.

\section{RESULTS AND DISCUSSION}

\section{Nutritional properties of the wild edible mushrooms}

In this study, 32 wild edible mushroom samples collected from different locations of Northeast India were assessed for their nutritional properties. Sample-wise as well as species-wise comparisons of the moisture content among different edible samples are represented in Table 2. The highest moisture content $(90.35 \mathrm{~g} / 100 \mathrm{~g})$ was recorded in Auricularia auricula-judae, while Polyporus arcularius (synonym. Lentinus arcularius) was recorded with the lowest moisture content 


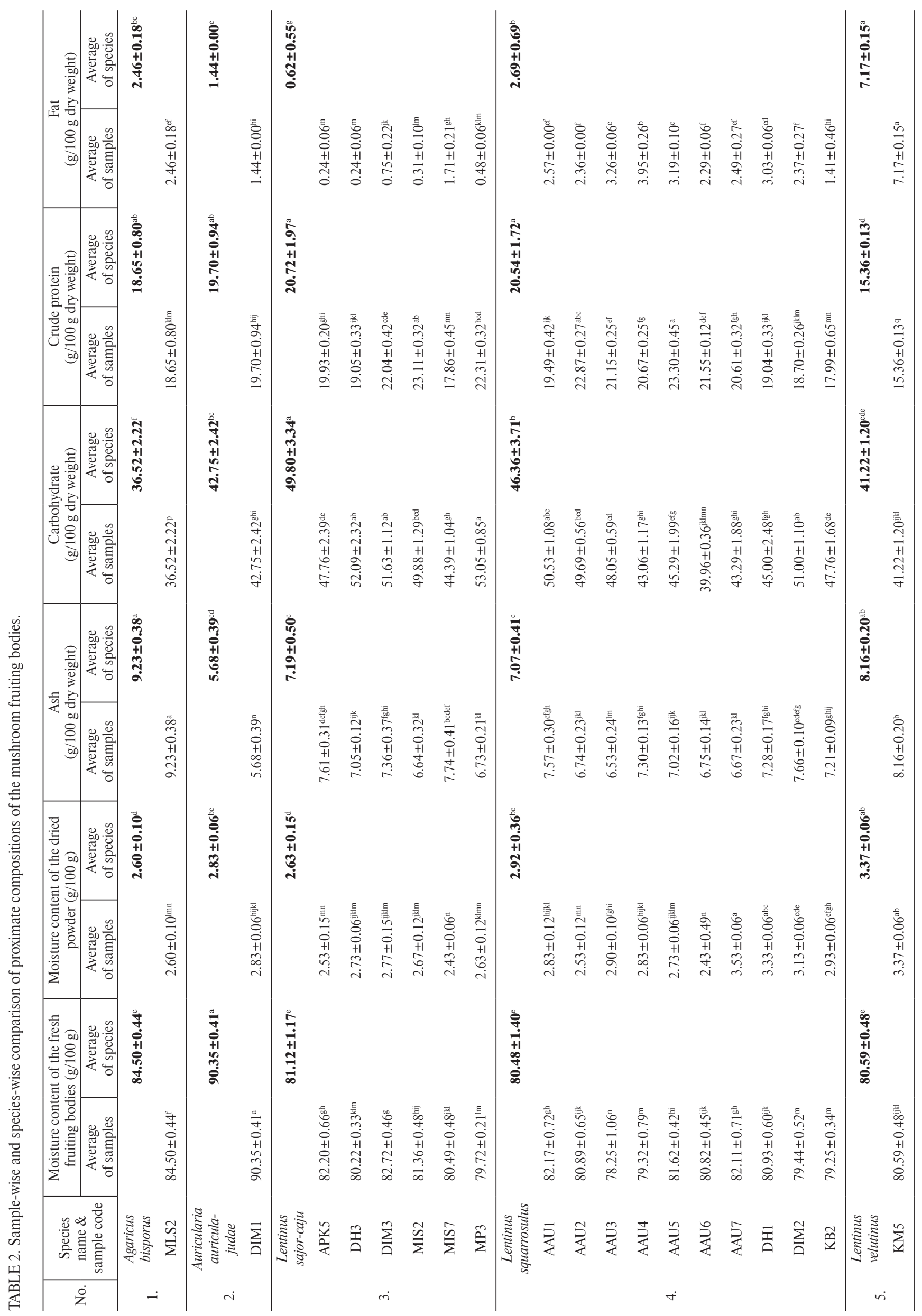




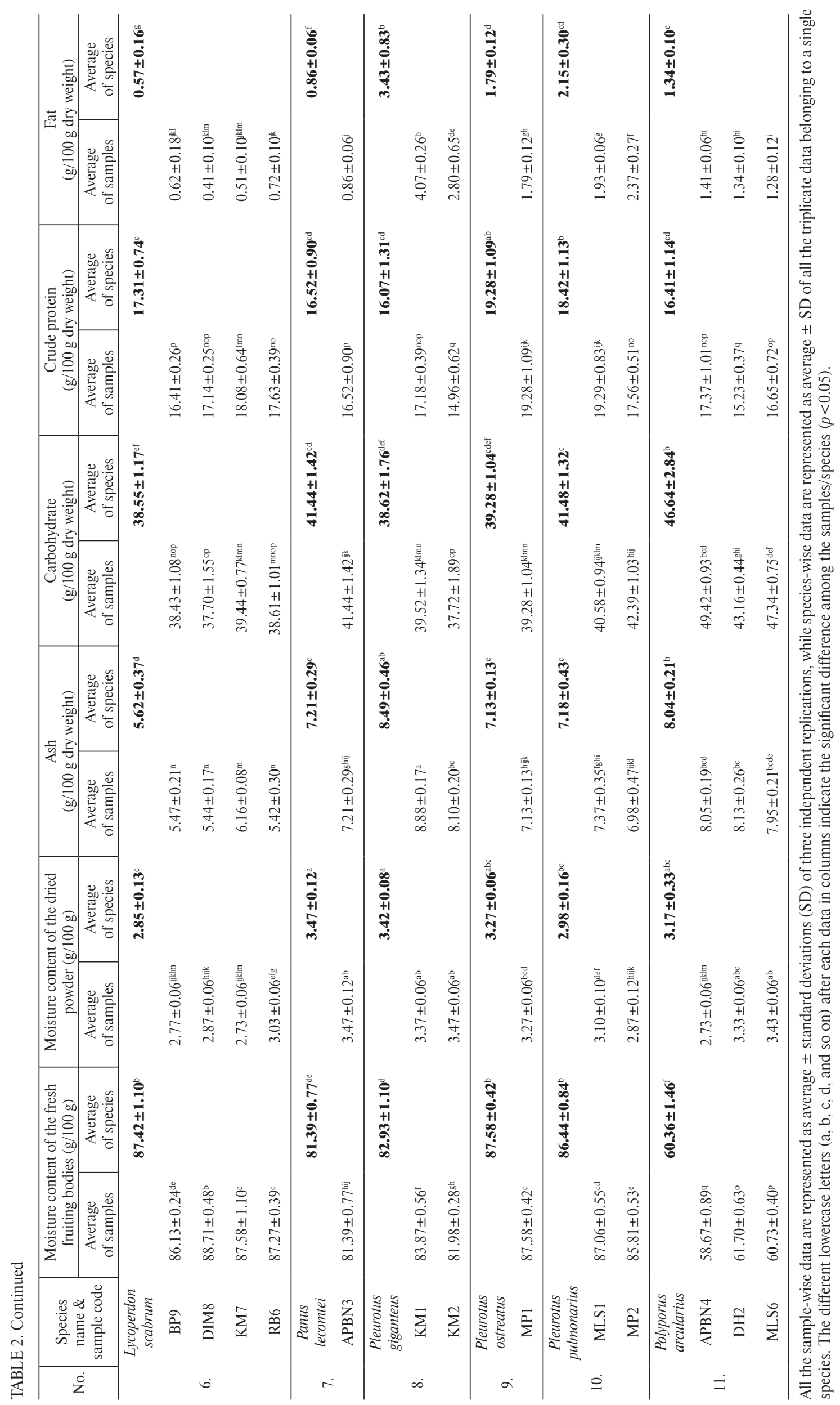


$(60.36 \mathrm{~g} / 100 \mathrm{~g})$. Moisture contents vary among species to species depending on their types of fruiting bodies. Although, differences in moisture content among the members of the same species may vary depending upon the environmental factors such as relative humidity, temperature, and relative amount of metabolic water [Crisan \& Sands, 1978; Singdevsachan et al., 2014]. Dry fruiting body powders of the mushrooms also retained the minimal amount of moisture ranging from $2.43 \mathrm{~g} / 100 \mathrm{~g}$ to $3.53 \mathrm{~g} / 100 \mathrm{~g}$ (Table 2). The highest ash content was determined in Agaricus bisporus (9.23 g/100 g d.w.), while the lowest one in Lycoperdon scabrum $(5.62 \mathrm{~g} / 100 \mathrm{~g}$ d.w.) and A. auricula-judae (5.68 g/100 g d.w.).

Total crude protein content of the edible dried mushrooms showed variations among different species (Table 2). Species-wise comparisons showed that the crude protein content was the highest in Lentinus sajor-caju $(20.72 \mathrm{~g} / 100 \mathrm{~g}$ d.w.), and Lentinus squarrosulus (20.54 g/100 g d.w.). Although, there were no significant differences $(p<0.05)$ observed in the crude protein content of these two species with that of A. auricula-judae (19.70 g/100 g d.w.), Pleurotus ostreatus $(19.28 \mathrm{~g} / 100 \mathrm{~g}$ d.w.) and A. bisporus $(18.65 \mathrm{~g} / 100 \mathrm{~g}$ d.w.). Our results were comparable to the previous findings on the protein contents of edible mushroom species [Kalač, 2013; Phan et al., 2012; Reis et al., 2012]. However, different researchers found differences in the protein contents based on the external growing parameters. For instance, the protein content in Pleurotus pulmonarius was reported to vary from $\sim 14 \mathrm{~g} / 100 \mathrm{~g}$ d.w. to $26 \mathrm{~g} / 100 \mathrm{~d}$.w. depending on different carbon sources supplemented during their cultivation process [Smiderle et al., 2012]. Therefore, it can be concluded that protein content in wild mushrooms may vary depending upon the substrates on which they grow.

Among the edible mushroom species, L. sajor-caju showed the highest carbohydrate contents $(49.80 \mathrm{~g} / 100 \mathrm{~g}$ d.w.), which was followed by $P$. arcularius $(46.64 \mathrm{~g} / 100 \mathrm{~g}$ d.w.), L. squarrosulus (46.36 g/100 g d.w.) and A. auricula-judae (42.75 g/100 g d.w.) (Table 2). Our results could be compared with the carbohydrate content of edible mushrooms as reported earlier [Johnsy et al., 2011; Nwanze et al., 2005]. Carbohydrates are the most abundant constituents of mushrooms, which include sugars (monosaccharides, their derivatives and oligosaccharides) as well as both reserved and construction polysaccharides [Kalač, 2013]. Compared to the small amount of reducing sugars present in mushrooms, chitin and starch constitute the major fraction of total carbohydrates [Manzi et al., 2001]. Mushrooms contain digestible carbohydratess (such as glucose, glycogen, mannitol, and trehalose) as well as non-digestible carbohydrate (such as $\beta$-glucan, chitin and mannans). Both of these carbohydrate forms constitute the total carbohydrates in mushroom fruiting bodies [Ho et al., 2020].

Species-wise comparison showed the highest total fat content in Lentinus velutinus (7.17 g/100 g d.w.), which was followed by Pleurotus giganteus ( $3.43 \mathrm{~g} / 100 \mathrm{~g}$ d.w.) and L. squarrosulus $(2.69 \mathrm{~g} / 100 \mathrm{~g}$ d.w.). The lowest total fat content was determined in the samples of $L$. scabrum $(0.57 \mathrm{~g} / 100 \mathrm{~g}$ d.w.) and L. sajor-caju (0.62 g/100 g d.w.) (Table 2). Typically, mushrooms have been reported to have a low fat content compared to the carbohydrate and protein contents. Fruiting bodies of edible mushrooms mostly contain cis-linoleic acid as a major fatty acid which varies from $22-65 \%$ in abundance of total fat. The other major fatty acids in mushrooms include cis-oleic acid, palmitic acid, and stearic acids [Günç Ergönül et al., 2013].

The mineral content analysis of the edible dried mushrooms revealed that there were significant differences among the tested samples. Table 3 and Table 4 show the specieswise average contents of macro- and microelements, respectively, of the mushroom samples. Among all the minerals, potassium $(\mathrm{K})$ content was the highest in all the samples. Species-wise comparison showed that potassium content varied among different species and the highest content was in P. ostreatus (2074.0 mg/100 g d.w.), along with A. bisporus, P. pulmonarius, $L$. squarrosulus, $L$. sajor-caju, A. auricula-judae and Panus lecomtei (Table 3). Previous studies also reported potassium as the predominant macroelement among different mushroom species [Dursun et al., 2006; Gençcelep et al., 2009]. The phosphorus content was the highest in L. velutinus $(318.8 \mathrm{mg} / 100 \mathrm{~g}$ d.w.), which was followed by that in P. pulmonarius $(294.3 \mathrm{mg} / 100 \mathrm{~g}$ d.w.) and P. ostreatus $(285.2 \mathrm{mg} / 100 \mathrm{~g}$ d.w.). The highest calcium (Ca) content was found in $L$. sajor-caju $(232.0 \mathrm{mg} / 100 \mathrm{~g}$ of d.w.), which was non-significantly higher $(p \geq 0.05)$ than in A. auricula-judae $(222.3 \mathrm{mg} / 100 \mathrm{~g}$ of d.w.), and few other species (Table 3). There were very little differences in the magnesium $(\mathrm{Mg})$ content among different species. The average sodium ( $\mathrm{Na}$ ) content of A. bisporus was the highest among the analysed mushroom species (Table 3). On the other hand, the lowest sodium content was found in P. lecomtei. Four microelements, namely iron $(\mathrm{Fe})$, zinc $(\mathrm{Zn})$, copper $(\mathrm{Cu})$, and manganese $(\mathrm{Mn})$, were also determined using atomic absorption spectroscopy (Table 4). The findings revealed exceptionally high iron content in A. auricula-judae $(97.30 \mathrm{mg} / 100 \mathrm{~g}$ d.w.) compared to the samples of other species. Iron contents of $L$. squarrosulus, $L$. sajor-caju, P. pulmonarius and A. bisporus were also found high. Compared to iron contents, other three elements $(\mathrm{Zn}, \mathrm{Cu}$ and $\mathrm{Mn})$ were determined at lower levels, which was consistent with findings of other authors [Dursun et al., 2006; Gençcelep et al., 2009]. As suggested by previous findings, the mineral contents of mushrooms are greatly affected by geographical locations, growing substrates and several other internal and external factors including growth conditions and genetic factors [Gençcelep et al., 2009; Mallikarjuna et al., 2013; Uzun et al., 2017]. It was also reported that bioavailability of some elements in mushrooms, especially copper, is low for human due to limited absorption from the small intestine [Schellmann et al., 1980].

\section{Total phenolic content (TPC) in the dry mushrooms}

Phenolic compounds are a major class of secondary plant metabolites with an important role in the protection against oxidation processes [Croft, 1999]. Numerous studies have proved that mushrooms also contain many phenolics equivalent to plant phenolics with potent radical scavenging ability [Elmastas et al., 2007; Turkoglu et al., 2007]. Here, total phenolic contents of the wild edible mushrooms were determined spectrophotometrically using the Folin-Ciocalteu reagent after extraction with methanol. Methanol can be considered 
as the most suitable solvent for the extraction of organic compounds including phenolics. Previously, it was reported that extraction of phenolics with methanol resulted in the highest TPC compared to ethanol, acetone and water [Do et al., 2020]. In the present study, the total phenolic content ranged from 59.2 to $1051.5 \mathrm{mg} \mathrm{GAE} / 100 \mathrm{~g}$ d.w. for the dried mushrooms (Table 5). Species-wise comparisons showed that the highest TPC was found in the samples of $L$. sajorсаju (831.3 mg GAE/100 g of d.w.), which was followed by P. lecomtei (780.9 mg GAE/100 g of d.w.) and P. pulmonarius. Samples belonging to the species $P$. arcularius had the lowest TPC (109.1 mg GAE/100 g of d.w.) compared to those of other species (Table 5). There are extensive reports concerning the phenolic contents of mushrooms; however, comparison of findings is difficult due to diversity in research materials, environmental conditions, habitats, analytical methods or ways of expressing the findings [Nowacka et al., 2014]. Our study demonstrated higher total phenolic contents in wild mushrooms (such as L. sajor-caju, P. ostreatus, and P. pulmonarius) compared to the cultivated strains of those species described earlier [Jeena et al., 2014]; however, total phenolic contents as high as $2.17-36.19 \mathrm{mg} / \mathrm{g}$ d.w. have been described earlier for a few edible mushrooms [Boonsong et al., 2016].

\section{Antioxidant activity}

DPPH radical scavenging activity of the mushroom samples was evaluated and the species-wise results were compared based on the $\mathrm{IC}_{50}$ of the methanolic extracts, as well as the tocopherol equivalent antioxidant activity (TEAA). The results suggested that the samples of the species $L$. sajorcaju, L. squarrosulus, and P. pulmonarius exhibited higher antioxidant activity indicated by the lower $\mathrm{IC}_{50}$ and higher TEAA as compared to other species (Table 5). IC $_{50}$ signifies the ability of the extract to scavenge the DPPH radical in a concentration-dependent manner. Based on the $\mathrm{IC}_{50}$, our results were comparable with those of earlier reports, which suggested that $40-60 \%$ inhibition of DPPH radical occurred in the presence of $\sim 500 \mu \mathrm{g} / \mathrm{mL}$ mushroom extracts [Boonsong et al., 2016]; although, concentrations as high as $5-20 \mathrm{mg} / \mathrm{mL}$ for scavenging 40-60\% of DPPH radical were also reported for few edible mushroom extracts [Cheung et al., 2003; Jeena et al., 2014; Wong \& Chye, 2009]. Extraction solvents play a crucial role in the determination of antioxidant activity of biological samples. Previous studies reported a high extraction yield of antioxidants from mushrooms with high antioxidant properties using methanol and ethyl acetate [Akata et al., 2019; Lakshmi et al., 2004]. In our study, there was a positive correlation between total phenolic content and TEAA, with a correlation coefficient of $0.544(p<0.01)$, suggesting the major role of phenolic compounds in antioxidant activity of mushroom powders. It was earlier reported that the antioxidant properties of button mushrooms varied between 5.49 and $10.48 \mathrm{nmol}$ Trolox equivalent/mg d.w. based on their growing stages, and the antioxidant activity of those samples correlated with the ergosterol content [Shao et al., 2010].

\section{Antihaemolytic activity}

Antihaemolytic activity of the extracts was tested in goat RBC cells in the presence of the haemolytic agent $\mathrm{H}_{2} \mathrm{O}_{2}$.
Extracts from the mushroom powders showed inhibition of haemolytic activity, which was found to be increased with increasing concentrations of the extracts (data not shown). Table 4 shows sample-wise and species-wise comparisons of the antihaemolytic activities of the dried fruiting body extracts. The samples belonging to the species L. sajor-caju, P. ostreatus, P. pulmonarius and A. bisporus showed the highest antihaemolytic activity compared to the samples of other species. Few extracts of $L$. squarrosulus indicated low $\mathrm{IC}_{50}$ values, suggesting to have prominent antihaemolytic activity. The antihaemolytic activity of the mushroom extracts can be correlated to their antioxidative potential, or total plenolic content [Afsar et al., 2016]. Haemolytic agents, like $\mathrm{H}_{2} \mathrm{O}_{2}$, oxidize the lipids in the plasma membrane of RBC cells, due to which haemoglobins release to the extracellular matrix. Phenolic compounds in the mushroom extracts inhibit the oxidation of lipids by $\mathrm{H}_{2} \mathrm{O}_{2}$ due to their antioxidant potential. There are plenty of reports demonstrating the antihaemolytic activity of phytoconstituents from different plant species [Alinezhad et al., 2013; Besbas et al., 2020; Chansiw et al., 2018]; however, only few studies have described the antihaemolytic potential of the extracts from the fruiting bodies of mushrooms. In an earlier study [Sharif et al., 2017], haemolytic inhibitory activity was evaluated in five different extracts (obtained using methanol, ethanol, ethyl acetate, $n$-hexane and water) of Ganoderma lucidum against human erythrocytes. The results suggested that two extracts (water and $n$-hexane) showed the antihaemolytic activity but, the other two extracts (ethyl acetate and ethanol) were detected as toxic. The decrease in toxicity of the five extracts was found to be in the order of ethyl acetate $>$ ethanol $>$ methanol $>n$-hexane $>$ water [Sharif et al., 2017].

\section{Content of organic acids, phenolic acids and vitamins (ascorbic acid and riboflavin) in mushrooms}

The presence of organic and phenolic acids and other metabolites in the mushroom extracts was determined using the HPLC analysis by comparing the retention times $\left(t_{R}\right)$ and the absorption maxima of the separated peaks with these of reference standards (supplementary Table S1). The chromatograms of selected mushroom extract (DIM1) and 11 commercially available reference substances used for the identification of mushroom powder compounds are shown in Figure 1. Few phenolic acids, including 3,4-dihydroxybenzoic acid $\left(\mathrm{t}_{\mathrm{R}}\right.$ : $10.2 \mathrm{~min})$, gallic acid $\left(\mathrm{t}_{\mathrm{R}}: 8.5 \mathrm{~min}\right)$, and trans-cinnamic acid $\left(\mathrm{t}_{\mathrm{R}}\right.$ : $15.4 \mathrm{~min}$ ), were identified in most of the tested samples (Table 6). Other non-phenolic acids, including ascorbic acids ( $\mathrm{t}_{\mathrm{R}}$ : $3.8 \mathrm{~min})$ and lactic acid $\left(\mathrm{t}_{\mathrm{R}}: 4.8 \mathrm{~min}\right)$, were also detected abundantly in most of the samples. Few other organic and phenolic acids, like citric acid $\left(\mathrm{t}_{\mathrm{R}}: 6.0 \mathrm{~min}\right)$, caffeic acid $\left(\mathrm{t}_{\mathrm{R}}: 9.7 \mathrm{~min}\right)$, vanillic acid $\left(\mathrm{t}_{\mathrm{R}}: 10.6 \mathrm{~min}\right)$, pyruvic acid $\left(\mathrm{t}_{\mathrm{R}}: 14.4 \mathrm{~min}\right)$, and $p$ coumaric acid $\left(\mathrm{t}_{\mathrm{R}}: 14.6 \mathrm{~min}\right)$, showed species-specific variation in their presence and contents (Table 6). Riboflavin was detected with moderate to low content (9-65 mg/100 g d.w.) in few species only. The presence of compounds with antioxidant activities has supported the earlier findings of this study. Previous studies also reported some major non-phenolic and phenolic acids, such as ascorbic acids, citric acid, caffeic acid, vanillic acid, gallic acid, and trans-cinnamic acid, in edible mushroom 


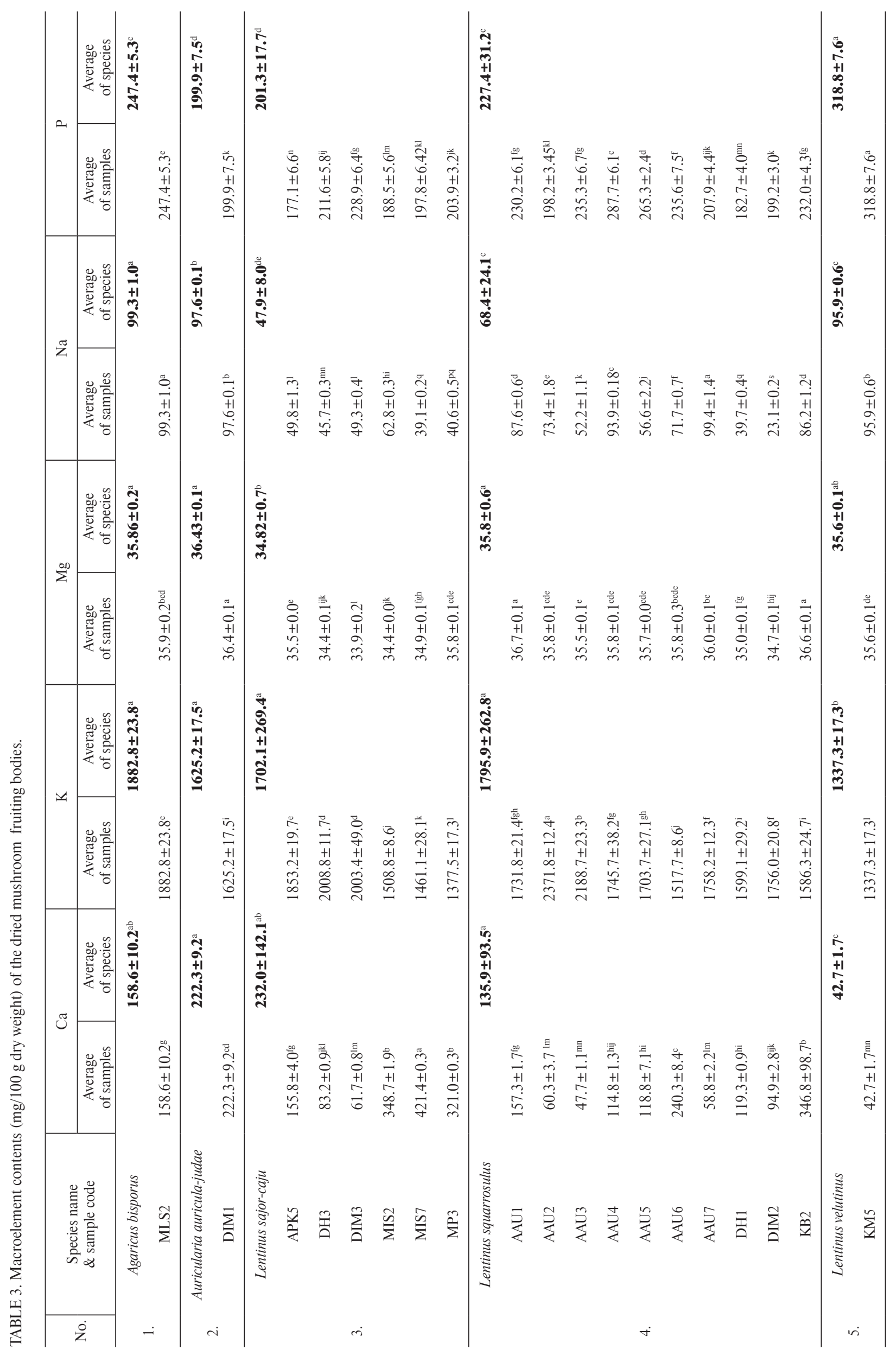




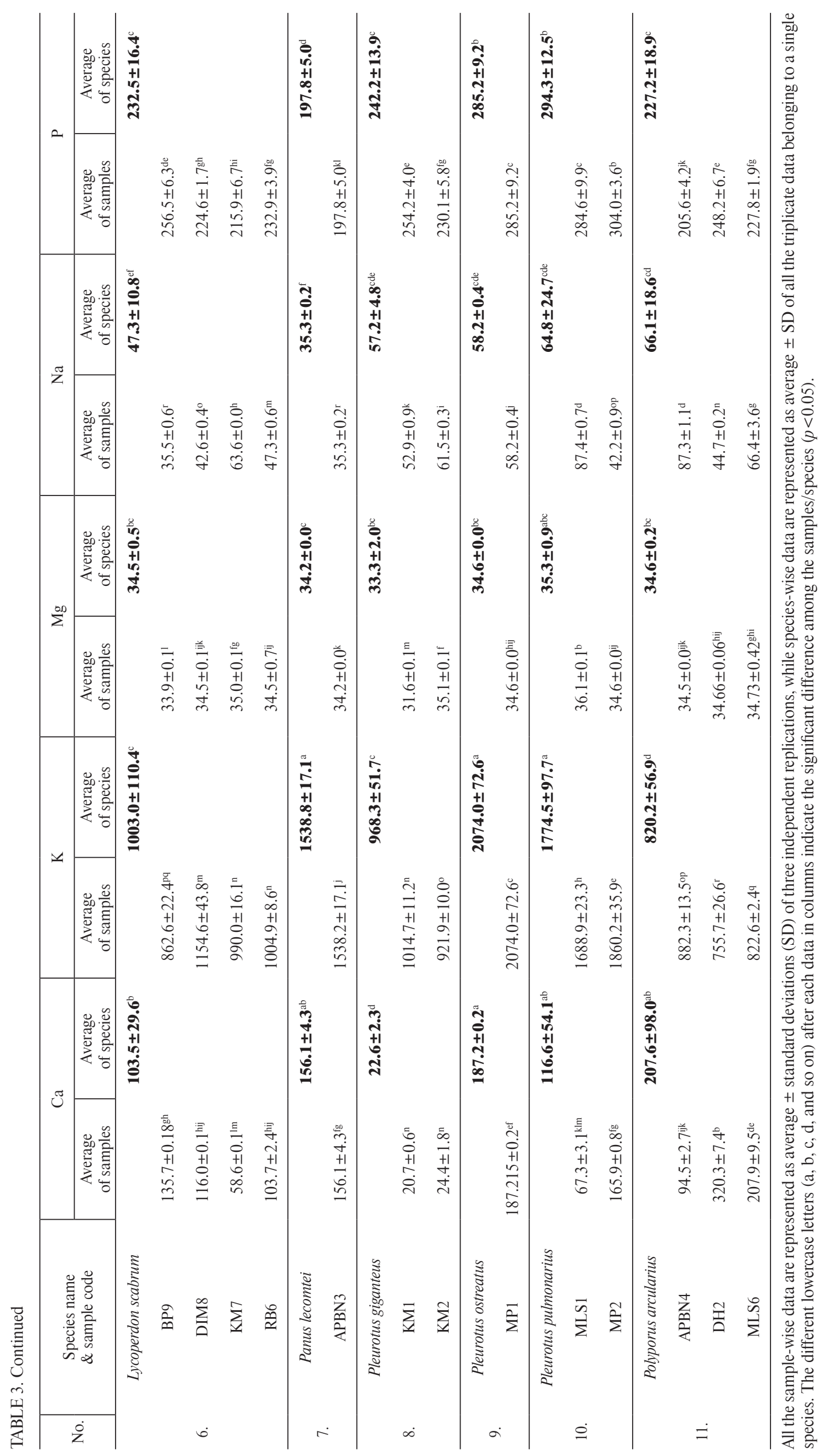


TABLE 4. Microelement contents ( $\mathrm{mg} / 100 \mathrm{~g}$ dry weight) of the dried mushroom fruiting bodies.

\begin{tabular}{|c|c|c|c|c|c|c|c|c|c|}
\hline \multirow{2}{*}{ No. } & \multirow{2}{*}{$\begin{array}{l}\text { Species name } \\
\& \text { sample code }\end{array}$} & \multicolumn{2}{|c|}{$\mathrm{Cu}$} & \multicolumn{2}{|c|}{$\mathrm{Fe}$} & \multicolumn{2}{|c|}{$\mathrm{Mn}$} & \multicolumn{2}{|c|}{$\mathrm{Zn}$} \\
\hline & & $\begin{array}{c}\text { Average } \\
\text { of samples }\end{array}$ & $\begin{array}{l}\text { Average } \\
\text { of species }\end{array}$ & $\begin{array}{c}\text { Average } \\
\text { of samples }\end{array}$ & $\begin{array}{l}\text { Average } \\
\text { of species }\end{array}$ & $\begin{array}{c}\text { Average } \\
\text { of samples }\end{array}$ & $\begin{array}{l}\text { Average } \\
\text { of species }\end{array}$ & $\begin{array}{c}\text { Average } \\
\text { of samples }\end{array}$ & $\begin{array}{l}\text { Average } \\
\text { of species }\end{array}$ \\
\hline \multirow{2}{*}{1.} & Agaricus bisporus & & $3.46 \pm 0.03^{\mathrm{a}}$ & & $24.73 \pm 1.15^{\text {bc }}$ & & $3.48 \pm 0.02^{b}$ & & $8.34 \pm 0.19^{a}$ \\
\hline & MLS2 & $3.46 \pm 0.03^{\mathrm{a}}$ & & $24.73 \pm 1.15^{\mathrm{kl}}$ & & $3.48 \pm 0.02^{\mathrm{fg}}$ & & $8.34 \pm 0.19^{c}$ & \\
\hline \multirow{2}{*}{2.} & $\begin{array}{l}\text { Auricularia } \\
\text { auricula-judae }\end{array}$ & & $1.98 \pm 0.03^{b}$ & & $97.30 \pm 4.52^{a}$ & & $15.15 \pm 0.61^{a}$ & & $7.15 \pm 0.39^{a b}$ \\
\hline & DIM1 & $1.98 \pm 0.03^{\mathrm{d}}$ & & $97.30 \pm 4.52^{\mathrm{a}}$ & & $15.15 \pm 0.61^{\mathrm{a}}$ & & $7.15 \pm 0.39^{\mathrm{e}}$ & \\
\hline \multirow{7}{*}{3.} & Lentinus sajor-caju & & $1.12 \pm 0.56^{c}$ & & $19.01 \pm 7.52^{\mathrm{c}}$ & & $2.54 \pm 0.64^{c}$ & & $4.60 \pm 0.51^{\mathrm{bc}}$ \\
\hline & APK5 & $1.57 \pm 0.01^{\mathrm{h}}$ & & $32.36 \pm 0.85^{\text {gh }}$ & & $3.50 \pm 0.16^{\mathrm{fg}}$ & & $5.45 \pm 0.07^{\mathrm{fg}}$ & \\
\hline & DH3 & $0.32 \pm 0.01^{q}$ & & $7.67 \pm 0.16^{\mathrm{rs}}$ & & $2.54 \pm 0.18^{1}$ & & $4.28 \pm 0.07^{\mathrm{klm}}$ & \\
\hline & DIM3 & $0.53 \pm 0.00^{\circ}$ & & $15.55 \pm 0.50^{\circ}$ & & $2.79 \pm 0.04^{\mathrm{jk}}$ & & $4.95 \pm 0.07^{\mathrm{hi}}$ & \\
\hline & MIS2 & $1.69 \pm 0.02^{g}$ & & $19.49 \pm 0.14^{\mathrm{n}}$ & & $1.58 \pm 0.04^{\circ}$ & & $4.01 \pm 0.05^{\mathrm{mnop}}$ & \\
\hline & MIS7 & $1.00 \pm 0.04^{\mathrm{k}}$ & & $19.85 \pm 0.53^{\mathrm{n}}$ & & $2.81 \pm 0.02^{\mathrm{jk}}$ & & $4.45 \pm 0.33^{\mathrm{k}}$ & \\
\hline & MP3 & $1.60 \pm 0.04^{\mathrm{h}}$ & & $19.17 \pm 0.04^{\mathrm{n}}$ & & $1.99 \pm 0.01^{\mathrm{n}}$ & & $4.49 \pm 0.24^{\mathrm{ik}}$ & \\
\hline \multirow{11}{*}{4.} & Lentinus squarrosulus & & $1.33 \pm 0.51^{c}$ & & $35.64 \pm 16.98^{b}$ & & $3.75 \pm 0.94^{b}$ & & $5.47 \pm 1.94^{\mathrm{abc}}$ \\
\hline & AAU1 & $1.62 \pm 0.03^{\mathrm{h}}$ & & $57.75 \pm 1.55^{\mathrm{c}}$ & & $4.70 \pm 0.04^{c}$ & & $8.76 \pm 0.17^{\mathrm{b}}$ & \\
\hline & AAU2 & $1.09 \pm 0.01^{\mathrm{j}}$ & & $40.77 \pm 1.31^{\mathrm{f}}$ & & $2.58 \pm 0.05^{1}$ & & $4.99 \pm 0.07^{\mathrm{h}}$ & \\
\hline & AAU3 & $0.70 \pm 0.01^{\mathrm{n}}$ & & $9.18 \pm 0.28^{9 \mathrm{r}}$ & & $5.00 \pm 0.04^{b}$ & & $3.67 \pm 0.12^{q}$ & \\
\hline & AAU4 & $1.33 \pm 0.02^{\mathrm{i}}$ & & $19.87 \pm 0.92^{\mathrm{n}}$ & & $4.51 \pm 0.06^{\mathrm{cd}}$ & & $4.34 \pm 0.11^{\mathrm{kl}}$ & \\
\hline & AAU5 & $0.72 \pm 0.02^{\mathrm{n}}$ & & $22.74 \pm 1.05^{\mathrm{m}}$ & & $4.40 \pm 0.08^{\mathrm{d}}$ & & $3.96 \pm 0.28^{\text {nop }}$ & \\
\hline & AAU6 & $1.87 \pm 0.04^{\mathrm{f}}$ & & $49.77 \pm 0.18^{\mathrm{d}}$ & & $2.22 \pm 0.01^{\mathrm{m}}$ & & $5.52 \pm 0.17^{\mathrm{fg}}$ & \\
\hline & AAU7 & $1.93 \pm 0.05^{\mathrm{e}}$ & & $26.58 \pm 0.85^{\mathrm{ij}}$ & & $2.99 \pm 0.04^{\mathrm{ij}}$ & & $5.54 \pm 0.13^{\mathrm{fg}}$ & \\
\hline & DH1 & $0.58 \pm 0.00^{\circ}$ & & $46.76 \pm 0.57^{\mathrm{e}}$ & & $3.22 \pm 0.09^{\mathrm{hi}}$ & & $4.35 \pm 0.11^{\mathrm{kl}}$ & \\
\hline & DIM2 & $1.58 \pm 0.01^{\mathrm{h}}$ & & $23.13 \pm 0.20^{\mathrm{lm}}$ & & $4.43 \pm 0.03^{\mathrm{d}}$ & & $4.14 \pm 0.09^{\operatorname{Imno}}$ & \\
\hline & KB2 & $1.87 \pm 0.04^{\mathrm{f}}$ & & $59.88 \pm 1.34^{\mathrm{b}}$ & & $3.41 \pm 0.05^{\text {gh }}$ & & $9.38 \pm 0.08^{\mathrm{a}}$ & \\
\hline \multirow{2}{*}{5.} & Lentinus velutinus & & $0.74 \pm 0.02^{\mathrm{cd}}$ & & $7.05 \pm 0.40^{e}$ & & $4.08 \pm 0.20^{b}$ & & $2.31 \pm 0.02^{d}$ \\
\hline & KM5 & $0.74 \pm 0.02^{\mathrm{mn}}$ & & $7.05 \pm 0.40^{\mathrm{s}}$ & & $4.08 \pm 0.20^{\mathrm{e}}$ & & $2.31 \pm 0.02^{\mathrm{r}}$ & \\
\hline \multirow{5}{*}{6.} & Lycoperdon scabrum & & $0.88 \pm 0.07^{c}$ & & $11.26 \pm 0.66^{d}$ & & $0.72 \pm 0.04^{d}$ & & $4.35 \pm 0.38^{c}$ \\
\hline & ВP9 & $0.97 \pm 0.02^{\mathrm{k}}$ & & $10.97 \pm 0.40^{\mathrm{p}}$ & & $0.76 \pm 0.02^{\text {qr }}$ & & $4.22 \pm 0.09^{\mathrm{klmn}}$ & \\
\hline & DIM8 & $0.88 \pm 0.02^{1}$ & & $12.13 \pm 0.59^{\mathrm{p}}$ & & $0.75 \pm 0.01^{\text {qr }}$ & & $3.90 \pm 0.08^{\text {орq }}$ & \\
\hline & KM7 & $0.78 \pm 0.03^{\mathrm{m}}$ & & $10.65 \pm 0.12^{\mathrm{pq}}$ & & $0.67 \pm 0.03^{\mathrm{rs}}$ & & $4.91 \pm 0.09^{\mathrm{hi}}$ & \\
\hline & RB6 & $0.88 \pm 0.02^{1}$ & & $11.28 \pm 0.07^{p}$ & & $0.72 \pm 0.01^{\text {qr }}$ & & $4.35 \pm 0.01^{\mathrm{kl}}$ & \\
\hline \multirow{2}{*}{7.} & Panus lecomtei & & $0.25 \pm 0.02^{d}$ & & $7.12 \pm 0.30^{e}$ & & $0.75 \pm 0.02^{d}$ & & $5.35 \pm 0.06^{\mathrm{abc}}$ \\
\hline & APBN3 & $0.25 \pm 0.02^{\mathrm{r}}$ & & $7.12 \pm 0.30^{\mathrm{s}}$ & & $0.75 \pm 0.02^{\text {qr }}$ & & $5.35 \pm 0.06^{\mathrm{g}}$ & \\
\hline \multirow{3}{*}{8.} & Pleurotus giganteus & & $0.86 \pm 0.48^{\mathrm{cd}}$ & & $5.95 \pm 2.84^{\mathrm{e}}$ & & $0.92 \pm 0.70^{d}$ & & $2.54 \pm 1.64^{d}$ \\
\hline & KM1 & $0.42 \pm 0.02^{\mathrm{p}}$ & & $3.37 \pm 0.21^{t}$ & & $0.29 \pm 0.06^{\mathrm{t}}$ & & $1.04 \pm 0.06^{\mathrm{s}}$ & \\
\hline & KM2 & $1.30 \pm 0.03^{\mathrm{i}}$ & & $8.53 \pm 0.39^{\mathrm{rs}}$ & & $1.55 \pm 0.06^{\mathrm{op}}$ & & $4.03 \pm 0.12^{\mathrm{mnop}}$ & \\
\hline \multirow{2}{*}{9.} & Pleurotus ostreatus & & $0.78 \pm 0.03^{\mathrm{cd}}$ & & $33.12 \pm 0.09^{b}$ & & $0.47 \pm 0.04^{d}$ & & $3.82 \pm 0.03^{d}$ \\
\hline & MP1 & $0.78 \pm 0.03^{\mathrm{m}}$ & & $33.12 \pm 0.09^{\mathrm{g}}$ & & $0.47 \pm 0.04^{\mathrm{st}}$ & & $3.82 \pm 0.03^{\mathrm{pq}}$ & \\
\hline \multirow{3}{*}{10.} & Pleurotus pulmonarius & & $1.43 \pm 0.64^{b c}$ & & $30.82 \pm 0.66^{b}$ & & $3.31 \pm 0.48^{b}$ & & $6.25 \pm 1.67^{\mathrm{abc}}$ \\
\hline & MLS1 & $2.02 \pm 0.02^{\mathrm{d}}$ & & $30.65 \pm 0.96^{\mathrm{h}}$ & & $3.69 \pm 0.38^{\mathrm{f}}$ & & $7.77 \pm 0.12^{\mathrm{d}}$ & \\
\hline & MP2 & $0.85 \pm 0.01^{1}$ & & $30.99 \pm 0.27^{\mathrm{h}}$ & & $2.94 \pm 0.04$ & & $4.72 \pm 0.01^{\mathrm{jj}}$ & \\
\hline \multirow{4}{*}{11.} & Polyporus arcularius & & $2.10 \pm 0.45^{b}$ & & $25.68 \pm 2.31^{b}$ & & $0.96 \pm 0.32^{d}$ & & $5.65 \pm 1.32^{\text {abc }}$ \\
\hline & APBN4 & $1.58 \pm 0.01^{\mathrm{h}}$ & & $23.03 \pm 0.22^{\mathrm{lm}}$ & & $1.33 \pm 0.03^{\mathrm{p}}$ & & $4.13 \pm 0.09^{\mathrm{Imno}}$ & \\
\hline & DH2 & $2.61 \pm 0.02^{\mathrm{b}}$ & & $28.25 \pm 0.16^{\mathrm{i}}$ & & $0.59 \pm 0.03^{\mathrm{rs}}$ & & $7.15 \pm 0.07^{\mathrm{e}}$ & \\
\hline & MLS6 & $2.10 \pm 0.11^{\mathrm{c}}$ & & $25.74 \pm 0.87 \mathrm{jk}$ & & $0.97 \pm 0.06^{q}$ & & $5.66 \pm 0.28^{\mathrm{f}}$ & \\
\hline
\end{tabular}

All the sample-wise data are represented as average \pm standard deviations (SD) of three independent replications, while species-wise data are represented as average $\pm \mathrm{SD}$ of all the triplicate data belonging to a single species. The different lowercase letters (a, b, $c, d$, and so on) after each data in columns indicate the significant difference among the samples/species $(p<0.05)$. 
TABLE 5. Total phenolic content, DPPH radical scavenging activity and antihaemolytic activity of the mushroom samples.

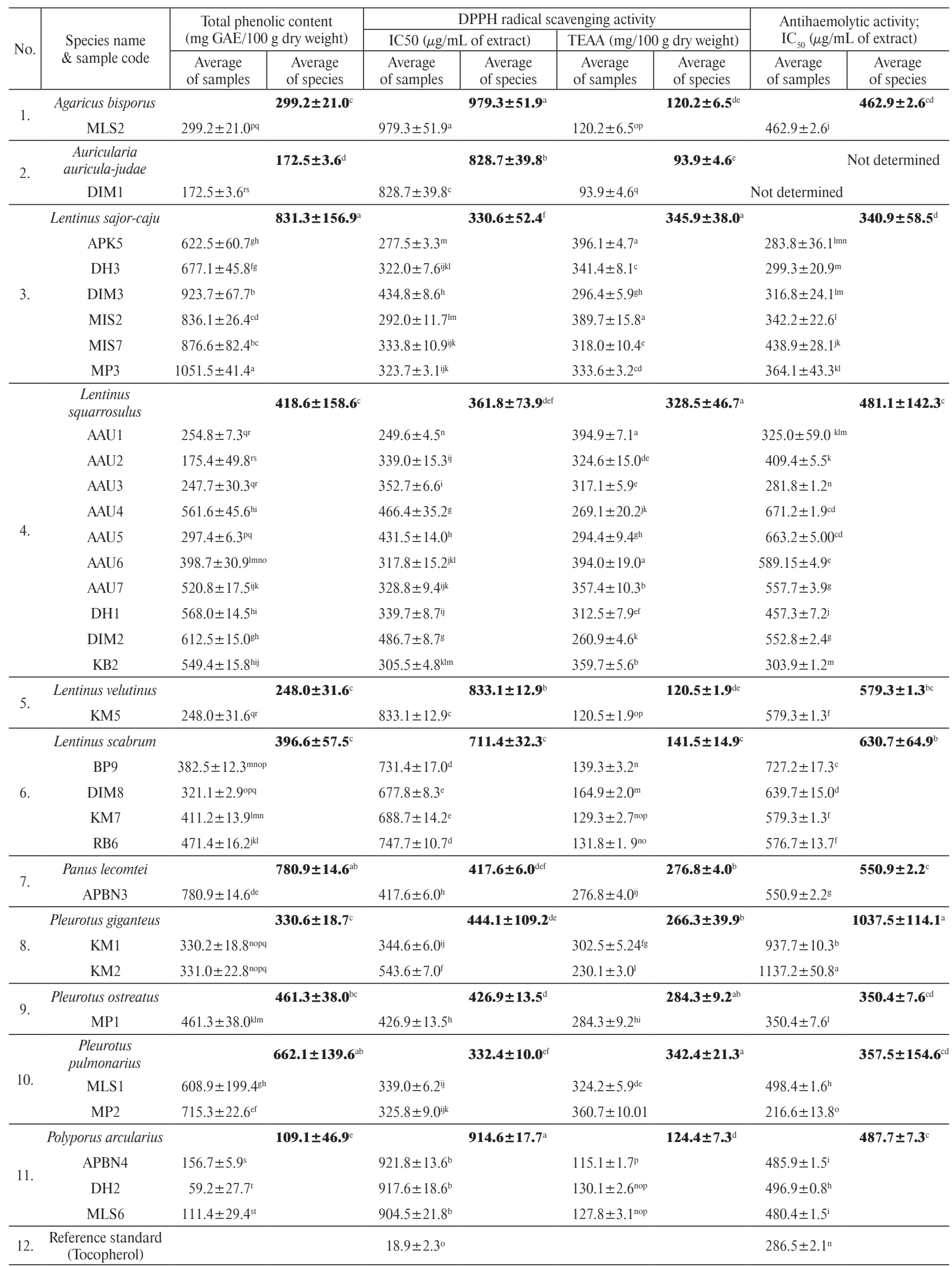

All the sample-wise data are represented as average \pm standard deviations (SD) of three independent replications, while species-wise data are represented as average $\pm \mathrm{SD}$ of all the triplicate data belonging to a single species. The different lowercase letters ( $\mathrm{a}, \mathrm{b}, \mathrm{c}, \mathrm{d}$, and so on) after each data in columns indicate the significant difference among the samples/species $(p<0.05)$. GAE: gallic acid equivalents; TEAA: tocopherol equivalent antioxidant activity. 


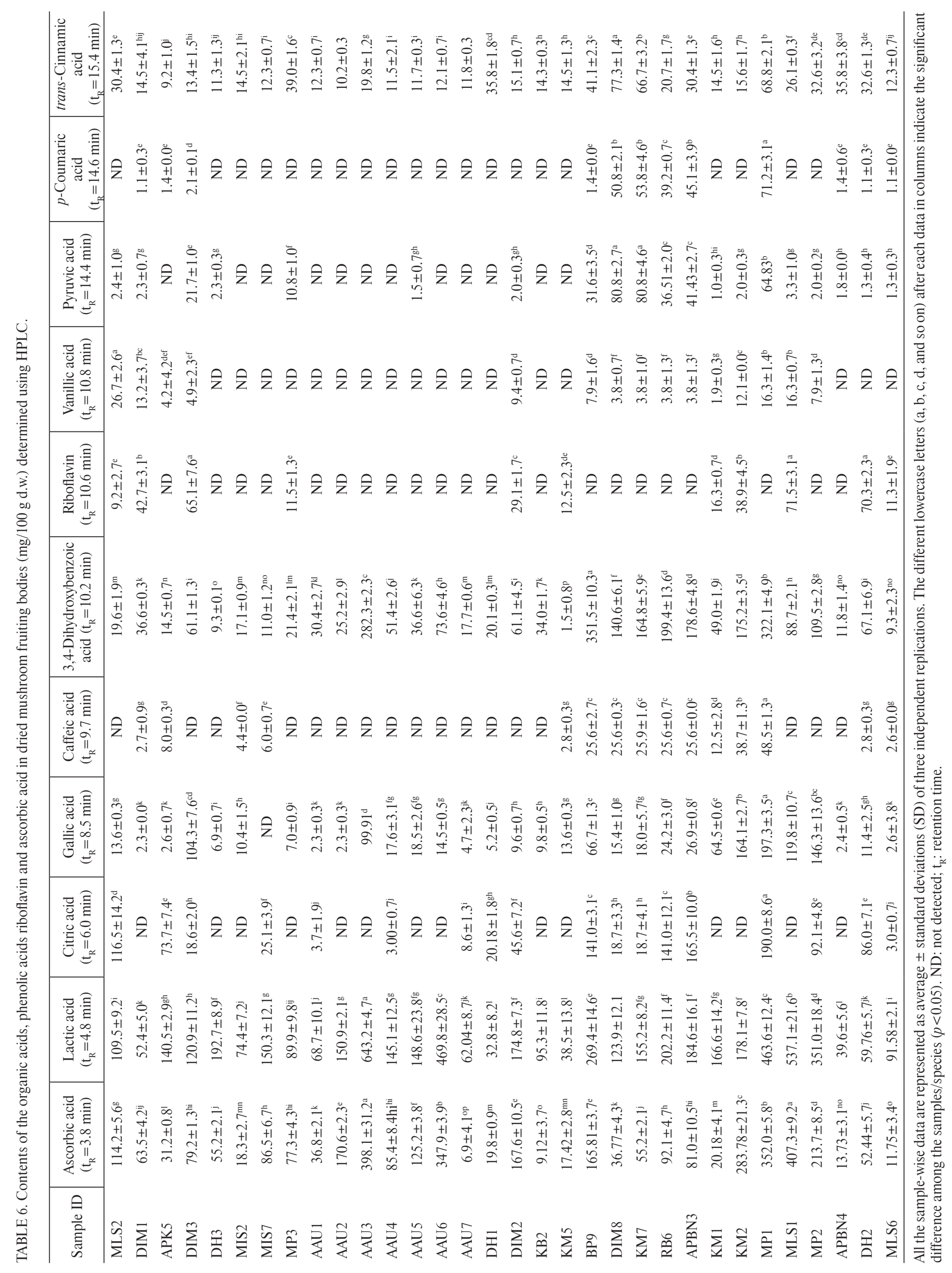




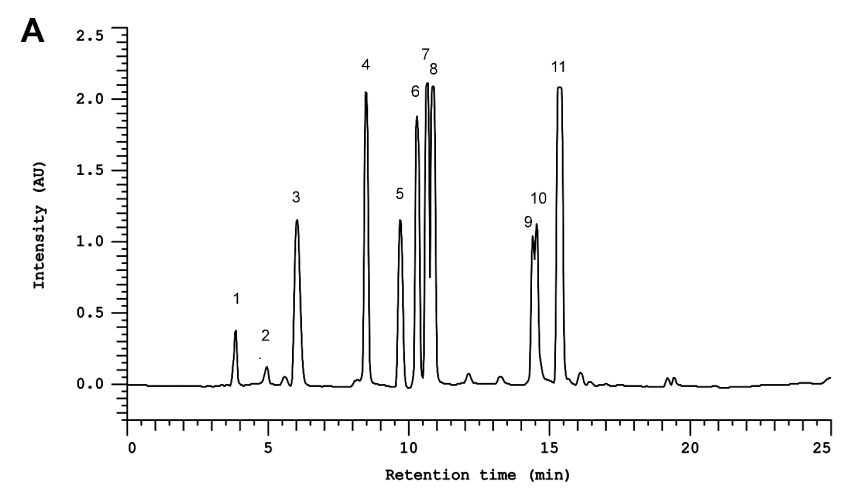

B

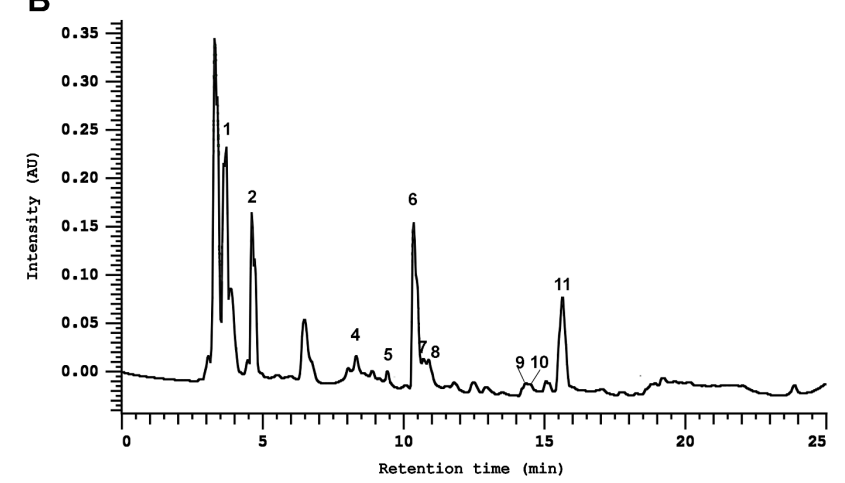

FIGURE 1. High performance liquid chromatography (HPLC) separation of the reference standards (A) and mushroom extract of DIM1 sample (B). Peaks for different compounds are designated with numbers: 1. ascorbic acid, 2. lactic acid, 3. citric acid, 4. gallic acid, 5. caffeic acid, 6. 3,4-dihydroxybenzoic acid, 7. riboflavin, 8. vanillic acid, 9. pyruvic acid, 10. p-coumaric acid, and 11.trans-cinnamic acid.

samples [Gąsecka et al., 2018; Valentão et al., 2005; Yahia et al., 2017]. It is noteworthy that apart from the selected peaks, there were other peaks in the HPLC chromatograms which were not identified using standards. Therefore, we do not deny the presence of other compounds in the mushroom extracts as they were not targeted for evaluation in this study. It was previously reported that the organic acid profile varied among different wild growing species of Agaricus, where lactic acid and succinic acid were found most abundantly in the tested mushrooms [Gąsecka et al., 2018]. In the present study, similar findings were recorded with heterogeneous distribution of organic acids among different mushroom species with intra-specific variations in the relative abundance of few organic acids. The presence of important phenolic acids in the fruiting bodies of edible mushrooms make them functional foods as they can protect human body from different diseases due to their strong antioxidant properties [Ribeiro et al., 2015; Valentão et al., 2005].

\section{CONCLUSIONS}

Based on the findings of our study, the dried edible mushrooms, especially $L$. sajor-caju and $L$. squarrosulus had a high nutritive value and a potent antioxidant activity. The samples of other mushroom species including, P. ostreatus, P. pulmonarius, A. bisporus and A. auricle-judae, also featured considerable nutritional and antioxidant properties. The high nutritional value of these wild edible mushrooms may enlighten their scope for domestication and cultivation, thereby contributing towards the complementation of food security and nutritional demands among the indigenous communities of Northeast India, especially, the people preferring the vegetarian diet. Moreover, mushroom extracts could be an emerging source of natural antioxidants, like phenolic acids (3,4-dihydroxybenzoic and trans-cinnamic acids) and ascorbic acid. Our study has demonstrated the antihaemolytic activity of several wild edible mushrooms from Northeast India, which contained several important organic acids and mentioned antioxidant metabolites. Consumption of such wild edible mushrooms with radical scavenging activity and antihaemolytic potential might be beneficial to combat oxidative damages in the human body.

\section{ACKNOWLEDGEMENTS}

The authors are grateful to the Department of Agricultural Biotechnology, Assam Agricultural University, Jorhat, Assam for providing laboratory space and facilities for conducting the present work. The authors are also thankful to DBT - North East Centre for Agricultural Biotechnology, Assam Agricultural University, Jorhat, Assam for providing necessary facilities and publication support.

\section{RESEARCH FUNDING}

This work was funded by the Science and Engineering Research Board (SERB), Department of Science and Technology, New Delhi, India, vide project sanction no. EEQ/2016/000631 without any influence over experimental design, findings and data interpretation. Article Processing Fee was received from DBT-North East Centre for Agricultural Biotechnology, Assam Agricultural University, Jorhat, Assam.

\section{CONFLICT OF INTEREST}

The authors declare that they have no conflict of interest.

\section{ORCID IDs}

M. Barooah https://orcid.org/0000-0002-3768-5336

R.C. Boro https://orcid.org/0000-0002-0866-3357

S. Dullah https://orcid.org/0000-0002-6433-2149

A. Ghosh https://orcid.org/0000-0001-8576-105X

D.J. Hazarika https://orcid.org/0000-0001-6370-4230

M. Kakoti https://orcid.org/0000-0002-5021-7692

A. Parveen https://orcid.org/0000-0002-9745-4118

D. Saha https://orcid.org/0000-0001-7258-9801

\section{SUPPLEMENTARY MATERIALS}

The following are available online at

http://journal.pan.olsztyn.pl/Nutritional-PropertiesAntioxidant-and-Antihaemolytic-Activities-of-the-Dry-Fruiting, $144044,0,2 . h t m l$

Supplementary Table S1: Retention times and absorption maxima of the 11 standards used for the identification of the compounds in the mushrooms. 


\section{REFERENCES}

1. Afsar, T., Razak, S., Khan, M.R., Mawash, S., Almajwal, A., Shabir, M., Haq, I.U. (2016). Evaluation of antioxidant, antihemolytic and anticancer activity of various solvent extracts of Acacia hydaspica R. Parker aerial parts. BMC Complementary and Alternative Medicine, 16(1), art. no. 258.

https://doi.org/10.1186/s12906-016-1240-8

2. Akata, I., Zengin, G., Picot, C.M.N., Mahomoodally, M.F. (2019). Enzyme inhibitory and antioxidant properties of six mushroom species from the Agaricaceae family. South African Journal of Botany, 120, 95-99.

https://doi.org/10.1016/j.sajb.2018.01.008

3. Alinezhad, H., Azimi, R., Zare, M., Ebrahimzadeh, M.A., Eslami, S., Nabavi, S.F., Nabavi, S.M. (2013). Antioxidant and antihemolytic activities of ethanolic extract of flowers, leaves, and stems of Hyssopus officinalis L. var. angustifolius. International Journal of Food Properties, 16(5), 1169-1178. https://doi.org/10.1080/10942912.2011.578319

4. AOAC. (1990). Official methods of analysis of the association of official analytical chemists (15th ed.). Association of Official Analytical Chemists International.

5. AOAC. (1996). Moisture in animal feed, Method 930.15. In Official Method of Analysis (16th ed.). Association of Official Analytical Chemists International.

6. AOAC. (2007). Fat by acid hydrolysis. In Official Methods of Analysis (18th Edith). Association of Official Analytical Chemists International.

7. Barros, L., Dueñas, M., Ferreira, I.C.F.R., Baptista, P., Santos-Buelga, C. (2009). Phenolic acids determination by HPLC-DAD-ESI/MS in sixteen different Portuguese wild mushrooms species. Food and Chemical Toxicology, 47(6), 1076-1079. https://doi.org/https://doi.org/10.1016/j.fct.2009.01.039

8. Besbas, S., Mouffouk, S., Haba, H., Marcourt, L., Wolfender, J.-L., Benkhaled, M. (2020). Chemical composition, antioxidant, antihemolytic and anti-inflammatory activities of Ononis mitissima L. Phytochemistry Letters, 37, 63-69.

https://doi.org/https://doi.org/10.1016/j.phytol.2020.04.002

9. Blois, M.S. (1958). Antioxidant determinations by the use of a stable free radical. Nature, 181(4617), 1199-1200.

https://doi.org/10.1038/1811199a0

10. Boonsong, S., Klaypradit, W., Wilaipun, P. (2016). Antioxidant activities of extracts from five edible mushrooms using different extractants. Agriculture and Natural Resources, 50(2), 89-97. https://doi.org/10.1016/J.ANRES.2015.07.002

11. Chang, R. (1996). Functional properties of edible mushrooms. Nutrition Reviews, 54(11), S91-S93.

https://doi.org/https://doi.org/10.1111/j.1753-4887.1996.tb03825.x

12. Chansiw, N., Paradee, N., Chotinantakul, K., Srichairattanakool, S. (2018). Anti-hemolytic, antibacterial and anti-cancer activities of methanolic extracts from leaves and stems of Polygonum odoratum. Asian Pacific Journal of Tropical Biomedicine, 8(12), 580-585.

https://doi.org/10.4103/2221-1691.248094

13. Cheung, L.M., Cheung, P.C.K., Ooi, V.E.C. (2003). Antioxidant activity and total phenolics of edible mushroom extracts. Food Chemistry, 81 (2), 249-255.

https://doi.org/10.1016/S0308-8146(02)00419-3
14. Crisan, E.V., Sands, A. (1978). Nutritional value. In S.T. Chang, W.A. Hayes (Eds.) The Biology and Cultivation of Edible Mushrooms, Chapter 6, Academic Press, pp. 137-168. https://doi.org/10.1016/B978-0-12-168050-3.50012-8

15. Croft, K.D. (1999). Antioxidant effects of plant phenolic compounds. In Antioxidants in Human Health and Disease, CABI Publishing, pp. 109-121.

http://www.academia.edu/download/6745089/Antioxidants_in_ Human_Health_and_Disease.pdf\#page $=129$

16. Do, T.H., Truong, H.B., Nguyen, H.C. (2020). Optimization of extraction of phenolic compounds from Ocimum basilicum leaves and evaluation of their antioxidant activity. Pharmaceutical Chemistry Journal, 54(2), 162-169.

https://doi.org/10.1007/s11094-020-02181-3

17. Dursun, N., Özcan, M.M., Kaşık, G., Öztürk, C. (2006). Mineral contents of 34 species of edible mushrooms growing wild in Turkey. Journal of the Science of Food and Agriculture, 86, 1087-1094. https://doi.org/10.1002/jsfa.2462

18. Elmastas, M., Isildak, O., Turkekul, I., Temur, N. (2007). Determination of antioxidant activity and antioxidant compounds in wild edible mushrooms. Journal of Food Composition and Analysis, 20(3-4), 337-345.

https://doi.org/10.1016/J.JFCA.2006.07.003

19. Gąsecka, M., Magdziak, Z., Siwulski, M., Mleczek, M. (2018). Profile of phenolic and organic acids, antioxidant properties and ergosterol content in cultivated and wild growing species of Agaricus. European Food Research and Technology, 244(2), 259-268.

https://doi.org/10.1007/s00217-017-2952-9

20. Gençcelep, H., Uzun, Y., Tunçtürk, Y., Demirel, K. (2009). Determination of mineral contents of wild-grown edible mushrooms. Food Chemistry, 113(4), 1033-1036. https://doi.org/10.1016/J.FOODCHEM.2008.08.058

21. Ghate, S.D., Sridhar, K.R. (2016). Contribution to the knowledge on macrofungi in mangroves of the southwest India. Plant Biosystems - An International Journal Dealing with All Aspects of Plant Biology, 150(5), 977-986. https://doi.org/10.1080/11263504.2014.994578

22. Günç Ergönül, P., Akata, I., Kalyoncu, F., Ergönül, B. (2013). Fatty acid compositions of six wild edible mushroom species. The Scientific World Journal, 2013, art. no. 163964. https://doi.org/10.1155/2013/163964

23. Hawksworth, D.L. (2001). Mushrooms: The extent of the unexplored potential. International Journal of Medicinal Mushrooms, $3(4)$, art. no. 5.

https://doi.org/10.1615/IntJMedMushr.v3.i4.50

24. Ho, L.-H., Zulkifli, N.A., Tan, T.-C. (2020). Edible mushroom: nutritional properties, potential nutraceutical values, and its utilisation in food product development. In A.K. Passari, S. Sánchez (Eds.), An Introduction to Mushroom. IntechOpen. https://doi.org/10.5772/intechopen.91827

25. Jeena, G.S., Punatha, H., Prakash, O., Chandra, M., Kushwaha, K.P.S. (2014). Study on in vitro antioxidant potential of some cultivated Pleurotus species (oyster mushroom). Indian Journal of Natural Products and Resources (IJNPR) [Formerly Natural Product Radiance (NPR)], 5(1), 56-61. http://14.139.47.23/index.php/IJNPR/article/view/12457

26. Johnsy, G., Sargunam, S.D., Dinesh M.G., Kaviyarasan, V. (2011). Nutritive value of edible wild mushrooms collected from 
the western ghats of Kanyakumari district. Botany Research International, 4(4), 69-74.

https://www.researchgate.net/publication/268270094

27. Kakoti, M., Hazarika, D.J., Kumar, A., Barooah, M., Modi, M.K., Bhattacharyya, A., Boro, R.C. (2021). Genetic diversity and dna barcoding of wild mushrooms from Northeast India. Iranian Journal of Science and Technology, Transactions A: Science, 45(2), 469-479.

https://doi.org/10.1007/s40995-021-01067-7

28. Kalač, P. (2013). A review of chemical composition and nutritional value of wild-growing and cultivated mushrooms. Journal of the Science of Food and Agriculture, 93(2), 209-218.

https://doi.org/10.1002/jsfa.5960

29. Khaund, P., Joshi, S.R. (2013). Wild edible macrofungal species consumed by the Khasi tribe of Meghalaya, India. Indian Journal of Natural Products and Resources, 4(2), 197-204.

30. Lakshmi, B., Tilak, J.C., Adhikari, S., Devasagayam, T.P.A., Janardhanan, K.K. (2004). Evaluation of antioxidant activity of selected Indian mushrooms. Pharmaceutical Biology, 42(3), 179-185. https://doi.org/10.1080/13880200490514023

31. Lindequist, U., Niedermeyer, T.H.J., Jülich, W.-D. (2005). The pharmacological potential of mushrooms. Evidence-Based Complementary and Alternative Medicine: ECAM, 2(3), 285-299. https://doi.org/10.1093/ecam/neh107

32. Madhanraj, R., Ravikumar, K., Maya, M.R., Ramanaiah, I., Venkatakrishna, K., Remeshkumar, K., Veeramanikandan, V., Eyini, M., Balaji, P. (2019). Evaluation of anti-microbial and anti-haemolytic activity of edible basidiomycetes mushroom fungi. Journal of Drug Delivery and Therapeutics, 9(1), 132-135.

https://doi.org/10.22270/jddt.v9i1.2277

33. Mallikarjuna, S.E., Ranjini, A., Haware, D.J., Vijayalakshmi, M.R., Shashirekha, M.N., Rajarathnam, S. (2013). Mineral composition of four edible mushrooms. Journal of Chemistry, 2013, art. no. 805284 .

https://doi.org/10.1155/2013/805284

34. Manzi, P., Aguzzi, A., Pizzoferrato, L. (2001). Nutritional value of mushrooms widely consumed in Italy. Food Chemistry, 73(3), 321-325.

https://doi.org/10.1016/S0308-8146(00)00304-6

35. Martins, A. (2017). The numbers behind mushroom biodiversity. In I.C.F.. Ferreira, P. Morales, L. Barros (Eds.), Wild Plants, Mushrooms and Nuts: Functional Food Properties and Applications, John Wiley Sons Ltd., pp. 15-50.

https://doi.org/10.1002/9781118944653.ch2

36. Nowacka, N., Nowak, R., Drozd, M., Olech, M., Los, R., Malm, A. (2014). Analysis of phenolic constituents, antiradical and antimicrobial activity of edible mushrooms growing wild in Poland. LWT - Food Science and Technology, 59(2), 689-694.

https://doi.org/10.1016/j.Iwt.2014.05.041

37. Nwanze, P.I., Khan, A.U., Ameh, J.B., Umoh, V.J. (2005). The effect of the interaction of various pond grains with different culture medium on carpophore dry weights and stipe and pilus diameters of Lentinus squarrosulus (Mont.) Singer. African Journal of Biotechnology, 4(7), 615-619.

https://doi.org/10.5897/AJB2005.000-3112

38. Parveen, A., Khataniar, L., Goswami, G., Hazarika, D.J., Das, P., Gautom, T., Barooah, M., Boro, R.C. (2017). A Study on the di- versity and habitat specificity of macrofungi of Assam, India. International Journal of Current Microbiology and Applied Sciences, 6(12), 275-297.

https://doi.org/10.20546/ijcmas.2017.612.034

39. Phan, C., Wong, W., David, P., Naidu, M., Sabaratnam, V. (2012). Pleurotus giganteus (Berk.) Karunarathna K.D. Hyde: Nutritional value and in vitro neurite outgrowth activity in rat pheochromocytoma cells. BMC Complementary Alternative Medicine, 2012, art. no. 102.

https://doi.org/10.1186/1472-6882-12-102

40. Reis, F., Barros, L., Martins, A., Ferreira, I. (2012). Chemical composition and nutritional value of the most widely appreciated cultivated mushrooms: an inter-species comparative study. Food and Chemical Toxicology, 50(2), 191-197.

https://doi.org/10.1016/j.fct.2011.10.056

41. Ribeiro, A., Ruphuy, G., Lopes, J.C., Dias, M.M., Barros, L., Barreiro, F., Ferreira, I.C.F.R. (2015). Spray-drying microencapsulation of synergistic antioxidant mushroom extracts and their use as functional food ingredients. Food Chemistry, 188, 612-618. https://doi.org/https://doi.org/10.1016/j.foodchem.2015.05.061

42. Sadasivam, S., Manickam, A. (1996). Biochemical Methods. New Age International.

https://books.google.co.in/books?hl=en\&lr=\&id=JuuwBg_D1 mIC \&oi=fnd\&pg=PR7\&ots=T4w6WVBltF\&sig=f03iwoOZEBxNKdhlYPh yaf8_SBo\&redir_esc=y\#v=onepage\&q\&f=false

43. Sánchez, C. (2017). Reactive oxygen species and antioxidant properties from mushrooms. Synthetic and Systems Biotechnology, 2(1), 13-22.

https://doi.org/https://doi.org/10.1016/j.synbio.2016.12.001

44. Sarma, T.C., Sarma, I., Patiri, B.N. (2010). Edible mushroom used by some ethnic tribes of western Assam. The Bioscan, 3(Special issue), 613-625.

https://doi.org/10.13140/RG.2.1.3531.1842

45. Schellmann, B., Hilz, M.-J., Opitz, O. (1980). Cadmium- und Kupferausscheidung nach Aufnahme von Champignon-Mahlzeiten (Fecal excretion of cadmium and copper after mushroom (Agaricus) diet). Zeitschrift Fur Lebensmittel-Untersuchung Und -Forschung, 171 (3), 189-192 (in German; English abstract). https://doi.org/10.1007/BF01042648

46. Shabbir, M., Khan, M.R., Saeed, N. (2013). Assessment of phytochemicals, antioxidant, anti-lipid peroxidation and anti-hemolytic activity of extract and various fractions of Maytenus royleanus leaves. BMC Complementary and Alternative Medicine, 13(1), art. no. 143 .

https://doi.org/10.1186/1472-6882-13-143

47. Shao, S., Hernandez, M., Kramer, J. K. G., Rinker, D.L., Tsao, R. (2010). Ergosterol profiles, fatty acid composition, and antioxidant activities of button mushrooms as affected by tissue part and developmental stage. Journal of Agricultural and Food Chemistry, 58(22), 11616-11625.

https://doi.org/10.1021/jf102285b

48. Sharif, S., Shahid, M., Mushtaq, M., Akram, S., Rashid, A. (2017). Wild mushrooms: A potential source of nutritional and antioxidant attributes with acceptable toxicity. Preventive $\mathrm{Nu}$ trition and Food Science, 22(2), 124-130. https://doi.org/10.3746/pnf.2017.22.2.124

49. Singdevsachan, S.K., Patra, J.K., Tayung, K., Sarangi, K., Thatoi, H. (2014). Evaluation of nutritional and nutraceutical poten- 
tials of three wild edible mushrooms from Similipal Biosphere Reserve, Odisha, India. Journal of Consumer Protection and Food Safety, 9(2), 111-120.

https://doi.org/10.1007/s00003-014-0861-4

50. Singleton, V.L., Rossi, J.A. (1965). Colorimetry of total phenolics with phosphomolybdic-phosphotungstic acid reagents. American Journal of Enology and Viticulture, 16(3), 144-158.

https://www.ajevonline.org/content/16/3/144.short

51. Smiderle, F.R., Olsen, L.M., Ruthes, A.C., Czelusniak, P.A., Santana-Filho, A.P., Sassaki, G.L., Gorin, P.A.J., Iacomini, M. (2012). Exopolysaccharides, proteins and lipids in Pleurotus pulmonarius submerged culture using different carbon sources. Carbohydrate Polymers, 87(1), 368-376.

https://doi.org/10.1016/J.CARBPOL.2011.07.063

52. Soylak, M., Saraçoğlu, S., Tüzen, M., Mendil, D. (2005). Determination of trace metals in mushroom samples from Kayseri, Turkey. Food Chemistry, 92(4), 649-652.

https://doi.org/10.1016/J.FOODCHEM.2004.08.032

53. Taylor, T.N., Krings, M., Taylor, E.L. (2015). Basidiomycota. In T.N. Taylor, M. Krings, E.L. Taylor (Eds.), Fossil Fungi, Academic Press, pp. 173-199.

https://doi.org/https://doi.org/10.1016/B978-0-12-387731-4.00009-8
54. Turkoglu, A., Duru, E., Mercan, N., Kivrak, I., Gezer, K. (2007). Antioxidant and antimicrobial activities of Laetiporus sulphureus (Bull.) Murrill. Food Chemistry, 101, 267-273.

https://doi.org/10.1016/j.foodchem.2006.01.025

55. Uzun, Y., Gençcelep, H., Kaya, A., Akçay, M.E. (2017). The mineral contents of some wild edible mushrooms. Journal of Fungus, 8(2), 178-183.

https://doi.org/10.15318/Fungus.2017.49

56. Valentão, P., Lopes, G., Valente, M., Barbosa, P., Andrade, P.B., Silva, B.M., Baptista, P., Seabra, R.M. (2005). Quantitation of nine organic acids in wild mushrooms. Journal of Agricultural and Food Chemistry, 53(9), 3626-3630.

https://doi.org/10.1021/jf040465z

57. Wong, J.Y., Chye, F.Y. (2009). Antioxidant properties of selected tropical wild edible mushrooms. Journal of Food Composition and Analysis, 22(4), 269-277.

https://doi.org/10.1016/J.JFCA.2008.11.021

58. Yahia, E.M., Gutiérrez-Orozco, F., Moreno-Pérez, M.A. (2017). Identification of phenolic compounds by liquid chromatography-mass spectrometry in seventeen species of wild mushrooms in Central Mexico and determination of their antioxidant activity and bioactive compounds. Food Chemistry, 226, 14-22.

https://doi.org/https://doi.org/10.1016/j.foodchem.2017.01.044 